\title{
Aggressive Fibromatosis of the Chest Wall: A Case Report with Magnetic Resonance Imaging and Histopathological Findings
}

\section{Gögüs Duvarı Agresif Fibromatozisi: Manyetik Rezonans Görüntüleme ve Histopatolojik Bulguları ile Birlikte Olgu Sunumu}

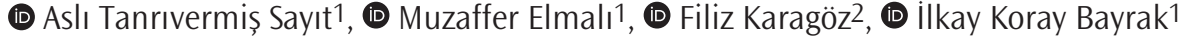 \\ 1 Ondokuz Mayıs University Faculty of Medicine, Department of Radiology, Samsun, Turkey \\ 20ndokuz Mayıs University Faculty of Medicine, Department of Pathology, Samsun, Turkey
}

\begin{abstract}
Fibromatosis represents a group of fibroblastic proliferations that vary from benign to intermediate in biological behavior. It can be classified as superficial or deep. Aggressive fibromatosis (AF) does not cause distant metastasis, the potential for local invasion and recurrence is very high. AF can be seen in various sites, including extra-abdominal, abdominal wall and intraabdominal locations. It is rare in the extra-abdominal area and may involve the muscles of the shoulder, pelvis and thigh. AF of the chest wall is rare, representing only $8-10 \%$ of all deep fibromatoses. Cross-sectional imaging modalities, especially magnetic resonance imaging (MRI), can be used to detect, characterize and show the extension of these tumors into adjacent tissues. MRI is superior to $\mathrm{CT}$ in the radiological evaluation of soft tissues. The signal intensity of AF varies depending on the collagen and water content of the cell. A radical surgical resection strategy with a safe margin $(2-3 \mathrm{~cm})$ remains the standard therapeutic approach for AF. However, radiotherapy is a significant treatment challenge, especially for young women. Herein, we present a 25-year-old female patient with recurrent chest wall AF extending to the breast, along with clinical findings, MR images, and histopathological findings.
\end{abstract}

Keywords: Aggressive fibromatosis, chest wall, ultrasonography, magnetic resonance imaging

\section{öz}

Fibromatozis biyolojik davranıșı benign ve intermediate arasında değişen bir grup fibroblastik proliferasyonu temsil eder. Yüzeyel ve derin olarak sınıflandırılabilir. Agresif fibromatozis (AF) uzak metastaz yapmaz ancak lokal invazyon ve rekürrens potansiyeli çok yüksektir. AF, ekstraabdominal, intrabdominal ve karın duvarında olmak üzere çeşitli yerlerde görülebilir. Ekstraabdominal alanda nadir olup omuz, pelvis ve uyluk kaslarında görülebilir. Göğüs duvarının AF'si nadir olup tüm derin fibromatozların yalnızca \%8-10'unu temsil eder. Kesitsel görüntüleme yöntemleri, özellikle manyetik rezonans görüntüleme (MRG), bu tümörleri saptamak, karakterize etmek ve komşu yumuşak dokulara yayılımını göstermek amacıyla kullanılabilir. MRG, yumuşak dokuların radyolojik değerlendirmesinde bilgisayarlı tomografiye (BT) oldukça üstündür. AF'nin sinyal intensitesi hücrenin kollajen ve su içeriğine bağlı olarak değişkenlik göstermektedir. AF'nin standart tedavisi güvenli marjlı $(2-3 \mathrm{~cm})$ radikal cerrahi rezeksiyondur. Bununla birlikte, radyoterapi, özellikle genç kadınlar için önemli tedavi yöntemlerindendir. Biz burada meme dokusuna uzanımlı rekürren göğüs duvarı AF'si olan 25 yaşında bayan hastayı klinik bulguları, MRG görüntüleri ve histopatalojik bulguları ile birlikte sunmayı amaçladık.

Anahtar Kelimeler: Agresif fibromatozis, gögüs duvarı, ultrasonografi, manyetik rezonans görüntüleme

\section{Introduction}

Fibromatosis is a benign, slow-growing tumor without any metastatic potential (1). These tumors are classified as superficial or deep (2). Deep fibromatosis, also known as desmoid tumors or aggressive fibromatosis (AF), can be intra-abdominal, within the abdominal wall, or extraabdominal. In several studies, 28-69\% of AF tumors were intra-abdominal (mesenteric or pelvic) or in the abdominal wall, and the remainder were extra-abdominal (3), 8-10\% of which were located in the chest wall (4). There is a slight preponderance in females and the peak incidence occurs in the third and fourth decades of life. AF is more aggressive in younger patients with recurrence rates of up to $87 \%$. Although AFs occur sporadically, they can also be seen as a part of familial adenomatous polyposis (FAP) and Gardner's syndrome (5). The estimated prevalence of sporadic AF in the general population is 2-4 per million per year, but the incidence of FAP-related AF is 3.5-32\% (6). 
Herein, we present a 25 -year-old female patient with recurrent chest wall AF extending to the breast with clinical, magnetic resonance imaging (MRI) and histopathological findings discussed.

\section{Case Report}

A 25-year-old female patient was admitted to the hospital with complaint of right breast swelling. Physical examination revealed a hard palpable mass in the right breast that was affixed to the chest wall. The patient had undergone right mastectomy for a $2 \times 3.5 \mathrm{~cm}$ mass with a histopathological diagnosis of AF approximately 3 years ago. Contrastenhanced and non-contrast-enhanced MRI of the breast and thorax were performed for the new palpable breast mass and they revealed a $6 \times 9 \mathrm{~cm}$ irregular-shaped mass with irregular margins extending into the right breast. The mass was isointense on T1-weighted images (T1-WI) (Figure 1) and hyperintense on fat-suppressed T2-WI. After intravenous contrast administration, the mass showed heterogeneous enhancement (Figure 2). MRI demonstrated invasion of the pectoral and intercostal muscles and the ribs. Fine needle aspiration biopsy was performed. Microscopically, the tumor was composed of fibroblastic spindle-shaped cells embedded in abundant collagenous tissue without epithelial components. Mitosis and atypia were not observed (Figure 3). The tumor cells were immunoreactive for smooth muscle actin and negative for desmin, CD34, and \$100. The proliferation rate assessed by the Ki-67 labeling index was $<1 \%$. This phenotype was consistent with the diagnosis of fibromatosis. Based on these findings, radiotherapy was recommended first and then a wide surgical excision was decided.

The patient gave informed consent for publication of the case.

\section{Discussion}

AF tumors are fibrous and fibrohistiocytic, and account for only $0.03 \%$ of all neoplasms $(7,8)$. Their etiology is not exactly known, but genetic, endocrine, and traumatic factors may play a role (6).

AF may arise in virtually any part of the body, but extra-abdominal AFs are rare. They have a predilection for the upper torso, including the upper arm (28\%), chest wall/paraspinal region (17\%) and head/neck (1023\%) (3). Chest wall AF tumors that extend through the breast have rarely been reported in the literature (9).

In ultrasonography, AF appears as an irregular hypoechoic mass with posterior acoustic shadowing, simulating a malignancy (3). In computed tomography (CT), AF appears as a non-specific soft tissue mass that may have ill-defined margins with contrast enhancement. Attenuation of these tumors is variable, described as lower than, similar to, and higher than that of skeletal muscle. MRI is considered superior to CT for detecting, characterizing, and showing the extension of the AF tumor to adjacent tissues. The signal intensity of these tumors is variable and depends on cellular variability, collagen content, and water content. T1WI most often demonstrates lesions with hypointense or intermediate signal intensity (isointense to muscle). On T2-WI, signal intensity is usually intermediate (isointense to muscle), occasionally with the presence of hypointense bands corresponding to collagen bundles. Lesions may also feature low or high signal intensity on T2-WI according to their contents $(3,7)$. Band-like regions of low signal intensity on T1-WI and T2-WI are more diagnostically important. These low signal intensity bands are common (62-91\%) in AF compared to other neoplastic lesions and are related to the collagenized, hypocellular bands seen on gross pathologic examination. These collagenized bands do not show contrast enhancement following gadolinium administration. This characteristic enhancement pattern has a sensitivity of $91 \%$. These low signal intensity bands are very useful for diagnosing AF (10). However, areas of low

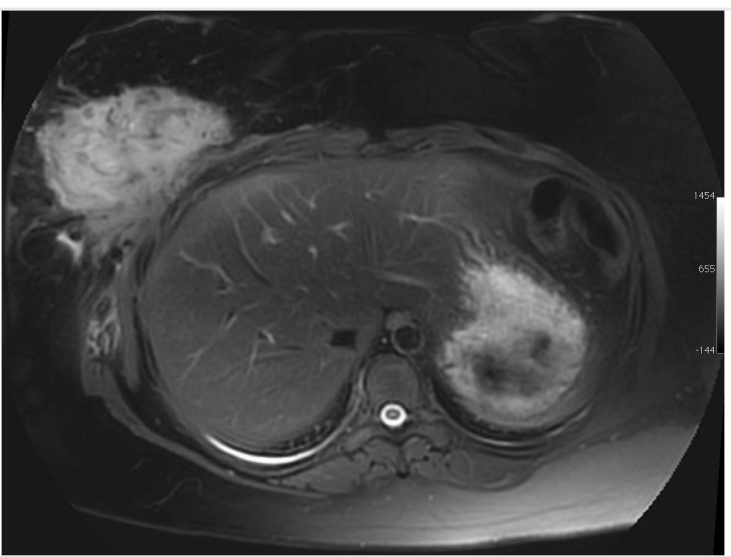

Figure 1. Axial T2-weighted fat-suppressed magnetic resonance image showing a large ill-defined heterogeneous mass in the right anterolateral chest wall extending to the breast that was hyperintense to skeletal muscle

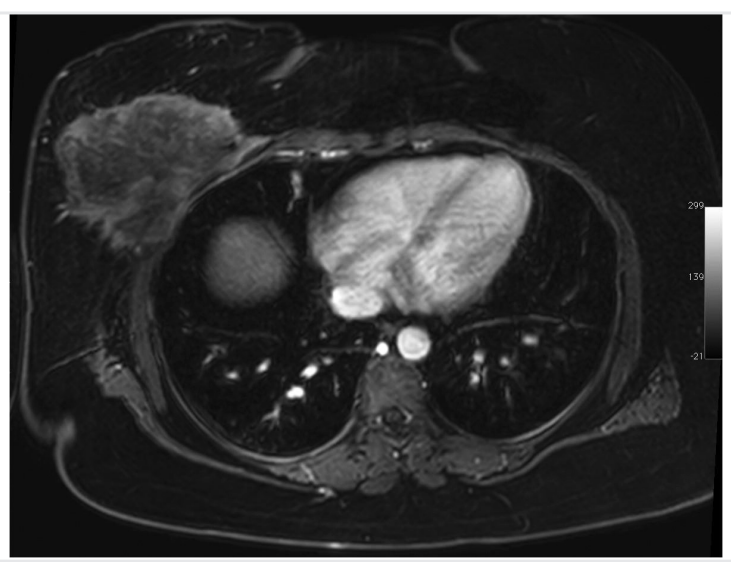

Figure 2. Axial T1-weighted fat-suppressed gadolinium-enhanced magnetic resonance image showing a heterogeneously enhancing mass. Lesion margins could not be distinguished from the adjacent ribs and intercostal muscles

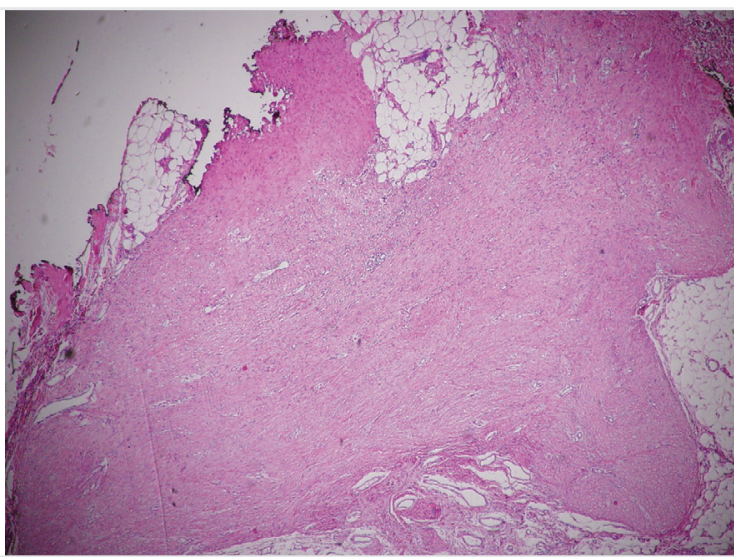

Figure 3. Histological features. Section stained with hematoxylin and eosin reveals uniform spindle cells (x100 magnification) 
T2-W signal are not specific to AF and may be seen in other lesions. Consequently, densely calcified mass, elastofibroma, granular cell tumor, desmoplastic fibroblastoma and malignant fibrous histiocytoma/ fibrosarcoma should be kept in mind in the differential diagnosis of soft-tissue lesions with prominent areas of low signal intensity on T1WI and T2-WI (3). In our case, the lesion was hypointense on T1-WI and hyperintense on T2-WI, without low signal intensity bands.

Surgical therapy, radiotherapy, systemic medical therapy, hormone therapy, anti-inflammatory drugs and tyrosine kinase inhibitors can be used to treat $\mathrm{AF}(10)$. However, the most effective and important treatment is aggressive surgical resection with negative margins $(2-3 \mathrm{~cm})$, as these tumors are locally aggressive with a high rate of recurrence. Incompletely excised lesions with positive surgical margins have a particularly high rate of local recurrence (1). Adjuvant radiotherapy is also recommended to reduce the risk of local recurrence despite negative margins $(6,10)$. However, radiotherapy is generally recommended only for unresectable tumors, gross or microscopic residual disease and recurrent disease (10). Our patient presented with a recurrent lesion within 3 years and was not given radiotherapy after surgery. Therefore, the treatment approaches were discussed and aggressive surgical resection was recommended after radiotherapy.

Although radiotherapy is useful to effect tumor death, early and late complications should always be kept in mind. In addition, monitoring should be done for radiation-induced breast carcinomas after radiotherapy for anterior chest wall tumors in young women (2). Postoperative radiotherapy was not applied to our patient due to her age. However, she presented with a newly developed recurrent chest wall tumor within 3 years. Therefore, a multidisciplinary approach should be followed for the treatment of these lesions.

Informed Consent: The patient gave informed consent for publication of the case.

Peer-review: Externally peer-reviewed.
Author Contributions: Surgical and Medical Practices - A.T.S., M.E., F.K., I.K.B.; Concept - A.T.S., M.E.; Design - A.T.S., M.E.; Data Collection and/ or Processing - A.T.S., F.K., I.K.B.; Analysis and/ or Interpretation - A.T.S., M.E.; Literature Search - A.T.S.; Writing Manuscript - A.T.S.

Conflict of Interest: No conflict of interest was declared by the authors.

Financial Disclosure: The authors declared that this study received no financial support.

\section{References}

1. Shen C, Zhou Y, Che G. Management of a female with recurrence of fibromatosis of the chest wall adjacent to the breast: a case report. J Cardiothorac Surg 2013; 8: 41.

2. Akhavan A, Binesh F, Kargar K, Navabii H. Juvenile female with chest wall fibromatosis located posteriorly to the right breast: radiation therapy or wait and watch? BMJ Case Rep 2013: 2013.

3. Walker EA, Petscavage JM, Brian PL, Logie CI, Montini KM, Murphey MD. Imaging features of superficial and deep fibromatoses in the adult population. Sarcoma 2012; 2012: 215810.

4. Foà R, Rizzo S, Petrella F, De Maria F, Bellomi M. Recurrent aggressive fibromatosis of the chest wall. Ecancermedicalscience 2014; 8: 464.

5. Shinagare $A B$, Ramaiya NH, Jagannathan JP, Krajewski KM, Giardino AA, Butrynski JE, et al. A to Z of desmoid tumors. AJR Am J Roentgenol 2011; 97: 1008-14.

6. Shields CJ, Winter DC, Kirwan WO, Redmond HP. Desmoid tumours. Eur J Surg Oncol 2001; 27: 701-6.

7. Tateishi U, Gladish GW, Kusumoto M, Hasegawa T, Yokoyama R, Tsuchiya R, et al. Chest wall tumors: radiologic findings and pathologic correlation: part 2. Malignant tumors. Radiographics 2003; 23: 1491-508.

8. Souza FF, Fennessy FM, Yang Q, van den Abbeele AD. Case report. PET/CT appearance of desmoid tumour of the chest wall. Br J Radiol 2010; 83: 39-42.

9. Shen C, Zhou Y, Che G. Management of a female with recurrence of fibromatosis of the chest wall adjacent to the breast: a case report. J Cardiothorac Surg 2013; 8: 41 .

10. Lee JC, Thomas JM, Phillips S, Fisher C, Moskovic E. Aggressive fibromatosis: MR features with pathologic correlation. AJR Am J Roentgenol 2006; 186: 247-54. 